\title{
Patterns of Treatment and Outcome in Patients With 20 or More Brain Metastases
}

\author{
CARSTEN NIEDER $^{1,2}$, ROSALBA YOBUTA $^{1}$ and BÅRD MANNSÅKER ${ }^{1}$ \\ ${ }^{1}$ Department of Oncology and Palliative Medicine, Nordland Hospital, Bod $\phi$, Norway; \\ ${ }^{2}$ Department of Clinical Medicine, Faculty of Health Sciences, \\ UiT - The Arctic University of Norway, Troms $\phi$, Norway
}

\begin{abstract}
Background/Aim: The aim of this study was to analyze the patterns of treatment and outcomes in patients with a large number of brain metastases, arbitrarily defined as 20 or more lesions. These patients are typically excluded from studies of focal brain treatment, e.g., surgery or radiosurgery, and might have a limited prognosis. Patients and Methods: This was a retrospective single-institution analysis. Overall, 11 patients were identified from a prospectively maintained database. Results: Ten patients had received active treatment $(9$ whole-brain radiotherapy, 7 systemic therapy). Median survival was 5.0 months without long-term survival beyond 13 months. Patients with better performance status had numerically longer survival, however we did not identify baseline parameters with a significant impact on survival. Conclusion: While long-term survival was not observed in this small study, most patients survived long enough to experience symptomatic improvement from whole-brain radiotherapy. Therefore, we recommend multidisciplinary assessment of the patients' prognosis and systemic treatment options, and initiation of whole-brain radiotherapy if survival is not limited to 1-2 months.
\end{abstract}

Advances in diagnostic imaging have facilitated detection of small intracranial lesions (1-3) and thus resulted in decreasing numbers of patients who present with 1-3 brain metastases from solid extracranial primary tumors, e.g., lung, breast, kidney cancer or malignant melanoma (4). Many patients with 1-3 brain metastases are considered adequate candidates for surgery and/or radiosurgery (SRS) (5-8). Technically, it is also

This article is freely accessible online.

Correspondence to: Dr. Carsten Nieder, Department of Oncology and Palliative Medicine, Nordland Hospital, 8092 Bodø, Norway. Tel: +47 75578449, Fax: +47 75534975, e-mail: carsten.nieder@nlsh.no

Key Words: Palliative radiotherapy, whole brain radiotherapy, brain metastases, number of metastases, prognostic factors, supportive care, cancer. feasible to irradiate more than three lesions with SRS, however there is no consensus about the maximum number of metastases that qualify for focal treatment, as opposed to whole-brain radiotherapy (WBRT) (9). Some groups have offered SRS to selected patients with 4-10 brain metastases, others also to those with even more lesions (10-13). With increasing lesion number, durable brain control is difficult to achieve. There is scarce data about the group of patients with a large number of brain metastases, and therefore we analyzed our Institution's prospectively maintained database. We arbitrarily decided to focus on patients with 20 or more brain metastases, a group which typically is excluded from studies of SRS or other focal treatments.

\section{Materials and Methods}

Patients and treatment. A retrospective study of patients with 20 or more synchronous or metachronous parenchymal brain metastases from histologically verified extracranial primary tumors treated at our hospital was performed. Treatment was individualized and consisted of WBRT, combined WBRT with systemic therapy or best supportive care (BSC). Systemic treatment was usually prescribed as judged appropriate by the patients' medical oncologists. The patients were treated between January 01, 2007 and December 31, 2017 and identified from a previously described database $(14,15)$. Brain magnetic resonance imaging was performed to assess the number of intracranial metastases and to exclude leptomeningeal disease.

Statistical methods. Overall survival (time to death) from the first day of radiotherapy or, in case of BSC, from imaging diagnosis was calculated employing the Kaplan-Meier method, and different groups were compared using the log-rank test (SPSS 24, IBM Corp., Armonk, NY, USA). Date of death was known in all patients. Statistical significance was defined as $p<0.05$ throughout this study in two-sided tests.

\section{Results}

Patient characteristics. Overall, 11 patients were identified from the database, corresponding to less than $5 \%$ of patients. Four patients had primary malignant melanoma and small cell lung cancer (SCLC), respectively. Non-small cell lung 
Table I. Patient characteristics.

\begin{tabular}{|c|c|c|c|c|c|c|c|c|c|c|c|c|c|}
\hline Diagnosis & $\begin{array}{l}\text { Time } \\
\text { interval } \\
\text { in } \\
\text { months }\end{array}$ & $\begin{array}{c}\text { Primary } \\
\text { tumor } \\
\text { controlled }\end{array}$ & $\begin{array}{l}\text { Extracranial } \\
\text { metastases }\end{array}$ & $\begin{array}{l}\text { Neurologic } \\
\text { symptoms }\end{array}$ & $\begin{array}{l}\text { Response } \\
\text { to } \\
\text { steroids }\end{array}$ & Treatment & $\begin{array}{l}\text { Systemic } \\
\text { therapy }\end{array}$ & KPS & $\begin{array}{l}\text { Diameter } \\
\text { of largest } \\
\text { lesion } \\
\text { in } \mathrm{cm}\end{array}$ & $\begin{array}{l}\text { Number } \\
\text { of } \\
\text { lesions }\end{array}$ & $\begin{array}{c}\text { Age } \\
\text { in } \\
\text { years }\end{array}$ & $\begin{array}{l}\text { Survival } \\
\text { in } \\
\text { months }\end{array}$ & $\begin{array}{l}\text { Cause } \\
\text { of } \\
\text { death }\end{array}$ \\
\hline $\begin{array}{l}\text { HER 2+ } \\
\text { breast cancer }\end{array}$ & 10 & Yes & Hep, oss & Yes & Yes & $\begin{array}{l}\text { WBRT } \\
30 \text { Gy }\end{array}$ & Trastuzumab & 70 & 1.9 & 50 & 50 & 10.2 & $\begin{array}{l}\text { Impossible to } \\
\text { determine }\end{array}$ \\
\hline $\begin{array}{l}\text { Adeno } \\
\text { NSCLC }\end{array}$ & 0 & No & Hep & Yes & No & $\begin{array}{c}1 \text { cycle CTx } \\
\text { died before } \\
\text { WBRT }\end{array}$ & No & 70 & 2.6 & 20 & 72 & 1.5 & $\begin{array}{c}\text { Likely } \\
\text { neurologic }\end{array}$ \\
\hline Melanoma & 156 & Yes & Pul, lym & Yes & No & $\begin{array}{l}\text { WBRT } \\
30 \mathrm{~Gy}\end{array}$ & $\begin{array}{c}\text { Dabrafenib + } \\
\text { Trametinib }\end{array}$ & -70 & 3.2 & 24 & 49 & 8.3 & Neurologic \\
\hline Melanoma & 33 & Yes & $\begin{array}{l}\text { Pul, adr, } \\
\text { oth }\end{array}$ & Yes & No & $\begin{array}{l}\text { WBRT } \\
30 \text { Gy }\end{array}$ & No & 60 & 3.0 & 21 & 67 & 2.0 & $\begin{array}{c}\text { Likely } \\
\text { neurologic }\end{array}$ \\
\hline $\begin{array}{l}\text { Adeno } \\
\text { NSCLC }\end{array}$ & 0 & Yes & Hep, oss & No & NA & $\begin{array}{l}\text { WBRT } \\
30 \mathrm{~Gy}\end{array}$ & CTx & 60 & 1.1 & 50 & 69 & 12.6 & $\begin{array}{l}\text { Likely non- } \\
\text { neurologic }\end{array}$ \\
\hline SCLC & 0 & No & No & No & NA & $\begin{array}{c}4 \text { cycles CTx, } \\
\text { then WBRT } \\
30 \mathrm{~Gy}\end{array}$ & CTx & 90 & 1.8 & 20 & 67 & 10.5 & $\begin{array}{l}\text { Likely non- } \\
\text { neurologic }\end{array}$ \\
\hline Melanoma & 28 & Yes & $\begin{array}{l}\text { Hep, pul, } \\
\text { oss }\end{array}$ & Yes & Yes & $\begin{array}{l}\text { WBRT } \\
40 \text { Gy with } \\
\text { temozo- } \\
\text { lomide }\end{array}$ & CTx & 80 & 3.6 & 25 & 40 & 2.3 & $\begin{array}{c}\text { Impossible to } \\
\text { determine }\end{array}$ \\
\hline SCLC & 6 & Yes & Hep, oss & Yes & $?$ & $\begin{array}{l}\text { WBRT } \\
30 \mathrm{~Gy}\end{array}$ & No & 60 & 1.0 & 36 & 72 & 5.0 & $\begin{array}{l}\text { Likely non- } \\
\text { neurologic }\end{array}$ \\
\hline Melanoma & 120 & No & $\begin{array}{l}\text { Pul, adr, } \\
\text { oth }\end{array}$ & Yes & Yes & $\begin{array}{l}\text { WBRT } \\
36 \text { Gy }\end{array}$ & CTx & 60 & 3.0 & 23 & 64 & 5.5 & $\begin{array}{c}\text { Impossible to } \\
\text { determine }\end{array}$ \\
\hline SCLC & 6 & Yes & $\begin{array}{l}\text { Hep, adr, } \\
\text { oss }\end{array}$ & Yes & No & $\begin{array}{l}\text { WBRT } \\
30 \text { Gy }\end{array}$ & No & 30 & 1.3 & 50 & 51 & 2.0 & $\begin{array}{c}\text { Non- } \\
\text { neurologic }\end{array}$ \\
\hline SCLC & 4 & No & $\begin{array}{l}\text { Hep, adr, } \\
\text { oth }\end{array}$ & Yes & Yes & $\begin{array}{c}\text { Converted } \\
\text { to BSC }\end{array}$ & No & 60 & 1.5 & 25 & 75 & 1.2 & $\begin{array}{l}\text { Likely non- } \\
\text { neurologic }\end{array}$ \\
\hline
\end{tabular}

NSCLC: Non-small cell lung cancer; SCLC: small cell lung cancer; hep: hepatic; oss: osseous; pul: pulmonary; lym: lymph nodes; adr: adrenal gland; oth: others; NA: not applicable; CTx: chemotherapy; WBRT: whole-brain radiotherapy; BSC: best supportive care; KPS: Karnofsky performance status.

cancer (NSCLC) was present in 2 patients, while one had a diagnosis of breast cancer. Only one patient had brain-only dissemination and two had Karnofsky performance status (KPS) $>70$. Further patient characteristics are shown in Table I, while imaging findings are displayed in Figure 1.

Treatment. Ten patients received active treatment, and one who initially was referred to WBRT was converted to BSC due to rapid deterioration of his KPS. Overall, nine patients received WBRT, commonly 10 fractions of $3 \mathrm{~Gy}$. Seven patients received systemic therapy after their brain metastases diagnosis.

Survival. Median overall survival of all 11 patients was 5.0 months (range=1.2-12.6 months). In the absence of systemic treatment, median survival was 2.0 months. If KPS was 70 or better, median survival was 8.3 months compared to 3.5 months if KPS was $<70(p=0.78)$. Age, size of the largest lesion, time interval between primary diagnosis and brain metastases, and other baseline variables were not significantly associated with survival either.

\section{Discussion}

We performed a retrospective study of patients with brain metastases and presumably limited prognosis due to the fact that the presence of many lesions rendered these patients ineligible for surgery or SRS, at least according to our institution's policy. SRS has recently gained increasing acceptance also in patients with more than just 1-2 brain metastases, because the probability of local lesion control is much higher after SRS than after WBRT, simply as a function of the higher ablative radiation dose delivered. In contrast, development of distant brain failure often results in need for further SRS or WBRT $(9,10)$. Besides local brain control, a variety of other factors that can be combined in prognostic scores are crucial determinants of long-term survival $(5,6,8,16,17)$.

Recent studies of SRS reported median numbers of metastases of 2 (range $=1-17$ metastases) (12) and 5 (range=4-23 metastases) (11), reflecting the different approaches chosen in different institutions. The latter study 


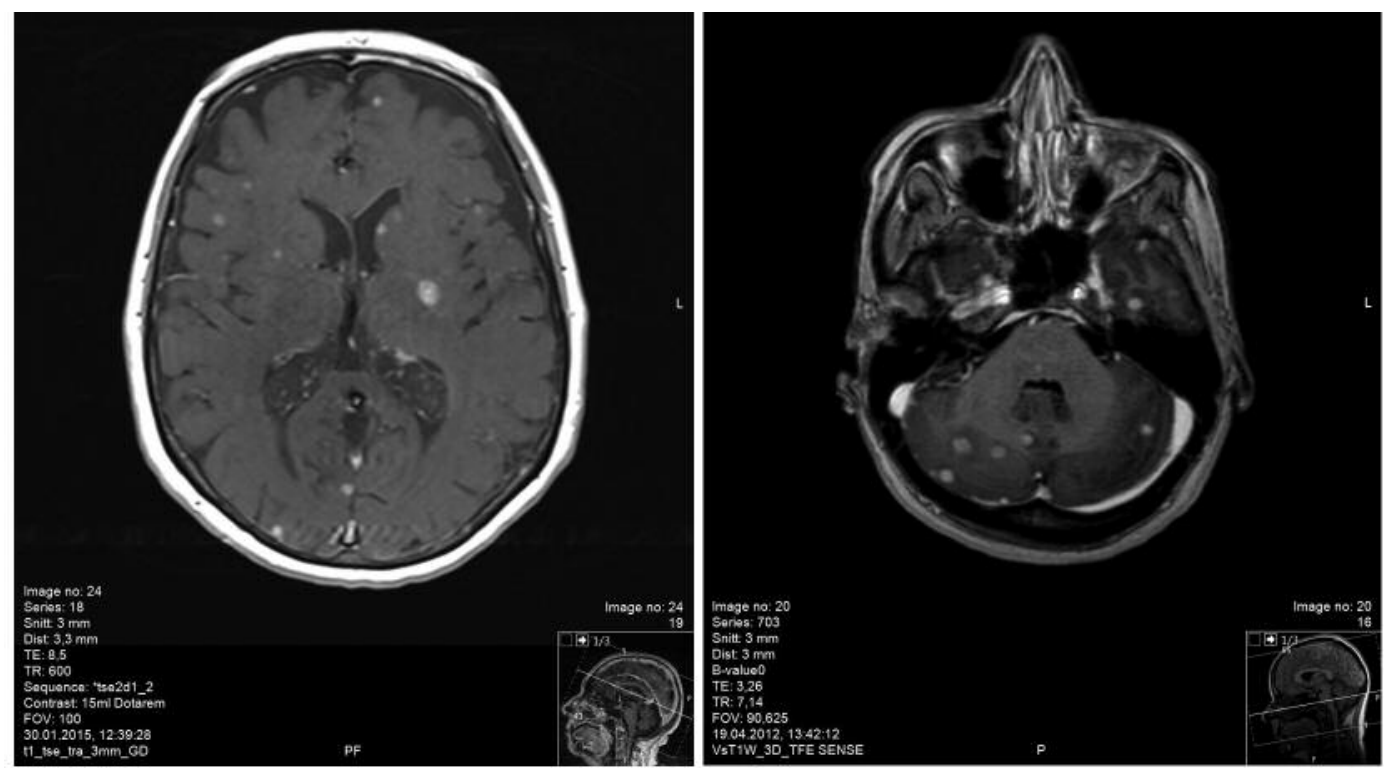

Figure 1. Magnetic resonance imaging scans of two study patients who presented with multiple contrast-enhancing brain metastases (examples of infra- (patient 7) and supratentorial (patient 5) disease extent, respectively).

of patients with at least four metastases reported better survival with smaller total tumor volume (11). Ali et al. (13) analysed more than 5,000 patients. The maximum number of metastases was not reported. The median survival of patients with $>10$ brain metastases was lower than that of those with 2-10 lesions (6.3 months vs. 5.5 months, $p=0.025)$. When lesion number was modelled as a continuous variable rather than using the cut-off, they observed a step-wise $4 \%$ increase in the hazard of death for every increment of 6-7 brain metastases $(p<0.001)$. In our study, median survival was 5.0 months and none of the patients had ever received SRS. Overall 5 patients survived for less than 3 months, emphasizing that careful selection is needed. Poor KPS and ineligibility for systemic therapy should be taken into consideration when deciding about WBRT. Since almost all patients had extracranial metastases, long-term survival is not purely a function of optimal local control in the brain. None of our patients had miliary brain metastases from EGFR mutated NSCLC, a special entity that may respond to targeted systemic therapy (18).

Chang et al. evaluated 323 patients who underwent SRS for metastatic brain lesions (19). Patients were divided into 4 groups according to the number of lesions visible on magnetic resonance (MR) images: Group 1, 1-5 lesions; Group 2, 6-10 lesions: Group 3, 11-15 lesions; and Group 4, $>15$ lesions. The overall median survival time after SRS was 10 months. The median survival time of each group was as follows: Group 1, 10 months; Group 2, 10 months; Group 3, 13 months; and Group 4, 8 months. There was no statistical difference between survival times after SRS $(p=0.554)$, although the probability of development of new lesions in the brain was greater in Group $4(p=0.014)$. Inter-study comparison of the survival outcomes is difficult, because Asian populations often include larger proportions of NSCLC patients with actionable mutations and also because patients managed with BSC were not included.

Limitations of the present study include the limited number of patients, statistical power of subgroup analyses, and its retrospective design. In many cases we were unable to firmly establish neurologic vs. other causes of death. Furthermore, quality of life data confirming the clinical benefit of WBRT and its potential neurocognitive impact were not available. A currently recruiting study is expected to provide relevant data in this context (20). CAR-Study B is a prospective randomized trial comparing cognitive outcome after SRS or WBRT in patients with 11-20 newly diagnosed brain metastases on a contrast-enhanced MRI scan, KPS $\geq 70$ and life expectancy of at least 3 months. Secondary endpoints include overall survival, local control, development of new brain metastases, cognitive functioning over time, quality of life, depression, anxiety and fatigue. Assessments are scheduled at baseline and at 3, 6, 9, 12 and 15 months after treatment.

\section{Conclusion}

While long-term survival was not observed in this small study, most patients survived long enough to experience 
symptomatic improvement from WBRT. Therefore, we recommend multidisciplinary assessment of the patients' prognosis and systemic treatment options, and initiation of WBRT if survival is not limited to 1-2 months.

\section{Conflicts of Interest}

The Authors declare that they have no competing interests.

\section{References}

1 Suh CH, Jung SC, Kim KW and Pyo J: The detectability of brain metastases using contrast-enhanced spin-echo or gradient-echo images: a systematic review and meta-analysis. J Neurooncol 129: 363-371, 2016.

2 Zakaria R, Das K, Bhojak M, Radon M, Walker C and Jenkinson MD: The role of magnetic resonance imaging in the management of brain metastases: diagnosis to prognosis. Cancer Imaging 14: 8, 2014.

3 Takamori S, Toyokawa G, Shimokawa M, Kinoshita F, Kozuma Y, Matsubara T, Haratake N, Akamine T, Mukae N, Hirai F, Tagawa T, Oda Y, Iwaki T, Iihara K, Honda H and Maehara Y: Radiological features of brain metastases from non-small cell lung cancer harboring EGFR mutation. Anticancer Res 38: 37313734, 2108.

4 Nieder C, Spanne O, Mehta MP, Grosu AL and Geinitz H: Presentation, patterns of care, and survival in patients with brain metastases: what has changed in the last 20 years? Cancer 117: 2505-2512, 2011.

5 Ampil F, Ellika S, Nanda A and Vora M: Long-term survival after stereotactic radiosurgery of brain metastases: A case series with 10-year follow-up. Anticancer Res 37: 5113-5115, 2017.

6 Rades D, Dziggel L and Schild SE: A specific survival score for patients receiving local therapy for single brain metastasis from a gynecological malignancy. In Vivo 32: 825-828, 2018.

7 Nieder C, Norum J, Stemland JG and Dalhaug A: Resource utilization in patients with brain metastases managed with best supportive care, radiotherapy and/or surgical resection: a Markov analysis. Oncology 78: 348-355, 2010.

8 Rades D, Blanck O, Khoa MT, VAN Thai P, Hung NQ, Dziggel $\mathrm{L}$ and Schild SE: Validation of a survival score for patients receiving radiosurgery or fractionated stereotactic radiotherapy for 1 to 3 brain metastases. In Vivo 32: 381-384, 2018.

9 Nieder C, Grosu AL and Gaspar LE: Stereotactic radiosurgery (SRS) for brain metastases: a systematic review. Radiat Oncol 9: 155, 2014.

10 Franchino F, Rudà R and Soffietti R: Mechanisms and therapy for cancer metastasis to the brain. Front Oncol 8: 161, 2018.

11 Limon D, McSherry F, Herndon J, Sampson J, Fecci P, Adamson J, Wang Z, Yin FF, Floyd S, Kirkpatrick J and Kim GJ: Single fraction stereotactic radiosurgery for multiple brain metastases. Adv Radiat Oncol 2: 555-563, 2017.
12 Sharma M, Jia X, Ahluwalia M, Barnett GH, Vogelbaum MA, Chao ST, Suh JH, Murphy ES, Yu JS, Angelov L and Mohammadi AM: Cumulative intracranial tumor volume and number of brain metastasis as predictors of developing new lesions after stereotactic radiosurgery for brain metastasis. World Neurosurg 106: 666-675, 2017.

13 Ali MA, Hirshman BR, Wilson B, Carroll KT, Proudfoot JA, Goetsch SJ, Alksne JF, Ott K, Aiyama H, Nagano O, Carter BS, Fogarty G, Hong A, Serizawa T, Yamamoto M and Chen CC: Survival patterns of 5750 stereotactic radiosurgery-treated patients with brain metastasis as a function of the number of lesions. World Neurosurg 107: 944-951, 2017.

14 Nieder C, Marienhagen K, Dalhaug A, Aandahl G, Haukland E and Pawinski A: Impact of systemic treatment on survival after whole brain radiotherapy in patients with brain metastases. Med Oncol 31: 927, 2014.

15 Nieder C, Norum J, Dalhaug A, Aandahl G and Pawinski A: Radiotherapy versus best supportive care in patients with brain metastases and adverse prognostic factors. Clin Exp Metastasis 30: 723-729, 2013.

16 Nieder C, Hintz M, Bilger A, Oehlke O and Grosu AL: Validation of the graded prognostic assessment for melanoma using molecular markers (melanoma-molGPA). J Clin Med Res 10: 178-181, 2018.

17 Nieder C, Hintz M, Oehlke O, Bilger A and Grosu AL: Validation of the graded prognostic assessment for lung cancer with brain metastases using molecular markers (lung-molGPA). Radiat Oncol 12: 107, 2017.

18 Hsu F, Nichol A, Toriumi T and De Caluwe A: Miliary metastases are associated with epidermal growth factor receptor mutations in non-small cell lung cancer: a population-based study. Acta Oncol 56: 1175-1180, 2017.

19 Chang WS, Kim HY, Chang JW, Park YG and Chang JH: Analysis of radiosurgical results in patients with brain metastases according to the number of brain lesions: is stereotactic radiosurgery effective for multiple brain metastases? J Neurosurg 113: 73-78, 2010.

20 Schimmel WCM, Verhaak E, Hanssens PEJ, Gehring K and Sitskoorn MM: A randomised trial to compare cognitive outcome after gamma knife radiosurgery versus whole brain radiation therapy in patients with multiple brain metastases: research protocol CAR-study B. BMC Cancer 18: 218, 2018.
Received October 26, 2018

Revised November 12, 2018

Accepted November 15, 2018 